\title{
Reference Values (RV), MNS and MTS for Morphological Characteristics of Normal and Abnormal Human Spermatozoon Describing Teratozoospermic Index (TZI) \& Sperm Deformity Index (SDI) in Sudanese Infertile Couples Using CASA System
}

\author{
Valores de Referencia (RV), MNS y MTS para las Características Morfológicas de Espermatozoides \\ Humanos Normales y Anormales que Describen el Índice Teratozoospérmico (TZI) y el Índice de \\ Deformidad del Esperma (SDI) en Parejas Infértiles de Sudán que Utilizan el Sistema CASA
}

Tarig Gasim Mohamed Alarabi ${ }^{1}$; Qurashi Mohamed Ali²; Asim M. Abdalla ${ }^{3}$; Heitham Muteakil Mohammed³; Mohamed Ebraheem ${ }^{4}$; Nidal Abubaker Harun ${ }^{5}$; Abulqasim M. B. Sideeg \& Ali Gad Karim A Salih

ALARABI, T. G. M. ; ALI, Q. M.; ABDALLA, A. M.; MOHAMMED, H. M.; EBRAHEEM, M.; HARUN, N. A.; SIDEEG, A. M. B. \& SALIH, A. G. K. A. Reference values (RV), MNS and MTS for morphological characteristics of normal and abnormal human spermatozoon describing teratozoospermic index (tzi) \& sperm deformity index (sdi) in sudanese infertile couples using CASA system. Int. J. Morphol., 37(3):1038-1045, 2019.

SUMMARY: A scientific determination of fertilization ability of the sperm can be made by motility, viability and morphological examinations that are called as potential fertility criteria. Some previous studies documented only the total morphological defect rates without including the morphologic subjects. As it is recorded in many studies, the success of IUI, ICSI and IVF depends mainly on the quality of the collected semen. 1) Determine and classify the common morphological defects and rates of sperms. 2) Analyze the effect of age on the sperm abnormalities and to assess the impact of environment on changing normal sperm characteristics. 3) Determine the common types of semen abnormalities (Asthenoterato-zoospermia, Asthenozoospermia, Azoopyospermia, Azoospermia, Hypospermia, Oligoasthenoteratozoospermia, Oligoasthenozoopyospermia, Oligoasthenozoospermia and Teratozoospermia). 4) Determine the range of teratozoospermic index (TZI) and sperm deformity index (SDI). A prospective case series study for 566 men of infertile couples who were requesting semen analysis was applied to those came to the ULTRALAB laboratory center main campus and ULTRALAB branch of the Sudan Assisted Reproduction Center (SARC), Khartoum, Sudan. Data collection was done for 20 months from April 1st, 2010 to December 31st, 2011. analysis of semen samples was done using Computer Assisted Semen Analysis (CASA). 1) The study demonstrates that there are differences in normality and abnormality of sperm morphology parameters of sperm between Sudanese population and other studies including WHO standards. 2) SDI and TZI were higher in overall semen as well as in abnormal semen samples. 3) Common semen abnormalities were oligoasthenoteratozoospermia, asthenoteratozoospermia and asthenozoospermia. There are differences in sperm morphology of both normal and abnormal parameters between Sudanese population and other studies including WHO standards.

KEY WORDS: Sperm; Semen; Sperm morphology.

\section{INTRODUCTION}

The human spermatozoa are incapable of in vivo fertilization at ejaculation. They must undergo maturational change in order to fertilize oocytes. The process, known as capacitation, has been described by Austin (1952) and defined as a period of time that sperm must reside in the female reproductive tract before they obtain the liability to fertilize oocytes (De Jonge, 2005). Capacitation is prevented in ejaculated spermatozoa by many factors that have negative effects (Austin, 1951). Prolonged exposure to seminal plasma inhibits the ability of the spermatozoa for undergoing an acrosome reaction in vitro and diminishes its capacity to fertilize. Motile spermatozoa separate themselves at the

\footnotetext{
${ }^{1}$ Department of Anatomy and Embryology, Orotta College of Medicine and Health Sciences, Eritrea.

${ }^{2}$ President, National University, Khartoum, Sudan.

${ }^{3}$ Department of Anatomy, Faculty of Medicine, King Khalid University, Saudi Arabia.

${ }^{4}$ Department of Health Rehabilitation Sciences, College of Applied Medical Sciences, Shaqra University, Saudi Arabia.

${ }^{5}$ College of Medicine, University of Science and Technology, Sudan.
} 
ALARABI, T. G. M. ; ALI, Q. M.; ABDALLA, A. M.; MOHAMMED, H. M.; EBRAHEEM, M.; HARUN, N. A.; SIDEEG, A. M. B. \& SALIH, A. G. K. A. Reference values (RV), MNS and MTS for morphological characteristics of normal and abnormal human spermatozoon describing teratozoospermic index (tzi) \& sperm deformity index (sdi) in sudanese infertile couples using CASA system. Int. J. Morphol., 37(3):1038-1045, 2019.

female genital tract from seminal plasma, immotile spermatozoa, and debris by migrating actively through the cervical mucus. A scientific determination of fertilization ability of the sperm cell can be made by motility, viability and morphological examinations that are called as potential fertility criteria. In addition to hereditary traits, semen quality is also affected by viability-weight and semen collection techniques. Spermatological characteristics are used for evaluating semen to be used for intra-uterine insemination (IUI), IVF or ICSI. There are limited studies concerning spermatozoon morphology and classification in Sudanese population. The available studies documented only the total morphological defect rates without including the morphologic subjects. As it is recorded in many studies, the success of artificial insemination and IVF depends mainly on the quality of the collected semen. The basic morphological structure of the spermatozoa is divided into the acrosome, head, mid-piece and tail. This research is believed to determine the proportion of defective (abnormal) spermatozoa in a semen sample of Sudanese population to assess fertility rate. The morphological defect types of human sperm assessed in vitro can be classified as: head abnormalities (malformations in the acrosomal region designated as acrosomal abnormalities and in the post - acrosomal region designated as nuclear abnormalities), sperm size variety, paired sperm, tail abnormality, sperm with multiple defects and cellular constituents of semen. Whereas there are also other types of classification that include: primary and secondary sperm defects and major and minor sperm defects. The primary defects described for that occur during the process of spermatogenesis whereas the secondary defects develop after sperm release process (Spermiation). Primary defects are originally caused by some type of direct insult to the seminiferous epithelium, and are not assumed to be more deleterious to fertility than secondary defects, that can be induced by various cause, including iatrogenic effects. Major and minor sperm defects' classification is based on the perceived adverse effect of sperm upon fertility. The major sperm defects include defects that are associated with impaired fertility, and the minor sperm defects include also defects that are considered to create some minor male fertility problems. In addition, major sperm defects are also classified as specific sperm defects that include: characterization of primary sperm defects, substantial proportion of the sperm population, consistent in occurrence, association with male infertility or sterility and heredity. To understand the etiologic factor for an abnormality of sperm cell, investigations based on semen analysis are obligatory because age, geographic and environmental conditions can affect potency (Menkveld et al., 2011). Some study results suggested effects of ozone, work process like metal workers and other chemicals have a negative effect on the sperm concentration, count, and morphology (Bonde, 2010; Hansen et al., 2010).

\section{MATERIAL AND METHOD}

Study Design and Participants. A prospective case series study for infertile male who had female couples who were requesting semen analysis was applied. Study participants were recruited from infertile couples who came to the ULTRALAB laboratory center main campus and ULTRALAB branch of the Sudan Assisted Reproduction Center (SARC), Khartoum, Sudan. Data collection was done for 20 months from April 1st, 2010 to December 31st, 2011. Study Setting and study period: The study was carried out for 566 infertile men, who had female couples who were requesting semen analysis, in the two ULTRALAB laboratory centers of Khartoum, Sudan. The data and sample collection were done for 20 months from April 1st, 2010 to December 31st, 2011.Study Approval: Ethical clearance was obtained from the ministry of health, Sudan, Khartoum and from the respective laboratory centers in Khartoum and individually from each patient. Data Analysis: The study date analysis was done by using CASA system that utilized modern computer and advanced image processing techniques for clinical test of quality of semen. System Components: 1 . PC include Mira9000 CASA software. 2. Mira9000 special slide. 3. Temperature controller. 4. Soft key. 5. Trinoculer Microscope with plan objective lens. 6. CCD camera (Minimum 480TV line). The system was standardized with WHO guidelines in order to obtain many analytic activities for the semen sample including the complete morphological analysis of sperm through comprehensively image processes.

\section{RESULTS}

\section{Morphology sperm analysis (Figs. 1 and 2)}

Percentage of normal sperms in overall normal and abnormal semen samples. Normal sperms percentage of the normal study samples ranged from 10.50 to 35.90 with mean of 18.81 and median 18.30 and standard deviation of 3.04. Normal sperms percentage of the abnormal study samples ranged from 0.00 to 93.80 with mean of 11.93 and median 11.29 and standard deviation of 7.00.

Mean of Normal-sperm (MNS) and Terato-sperm (MTS) of the overall samples (Table I). The mean of head morphology parameters of normal sperm (MNS) and terato sperm (MTS) of the overall samples were also found to be $2.86 \mu \mathrm{m}, 2.08 \mu \mathrm{m}, 1.60$ percent, 5.98, 9.93, and 30.46 percent for head_length, head_width, length/width, head_area, head_perimeter, and acrosome, respectively for the MNS. Whereas it was also identified as $4.07 \mu \mathrm{m}, 2.68 \mu \mathrm{m}, 1.60$ 

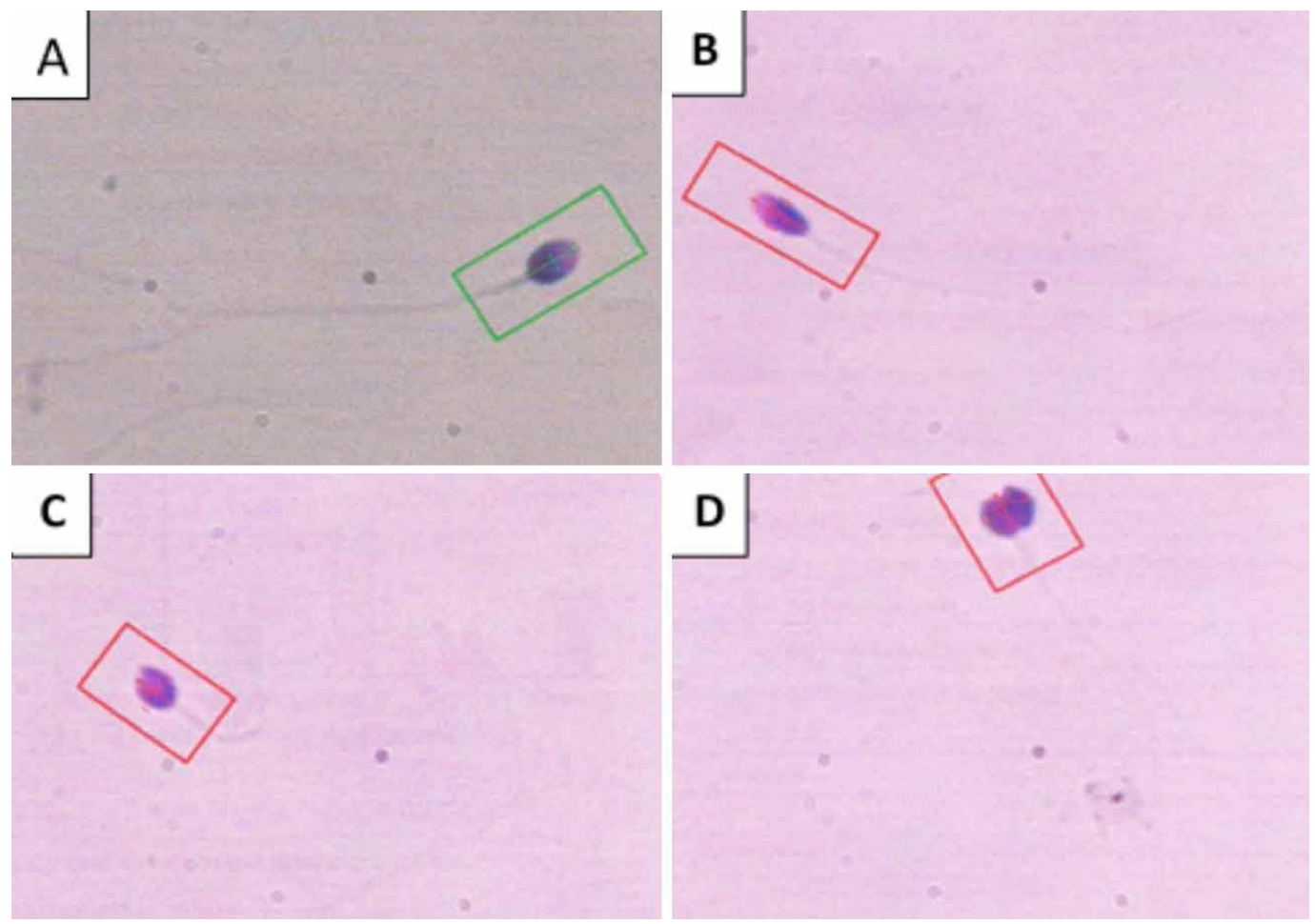

Fig. 1. Mira-9000 CASA analyzer trinoculer light microscope with plan objective lens CCD camera shows A. normal sperm head (green square). the next were abnormal (red squares) including: B. tapered sperm head. C. amorphous sperm head. D. round sperm head.

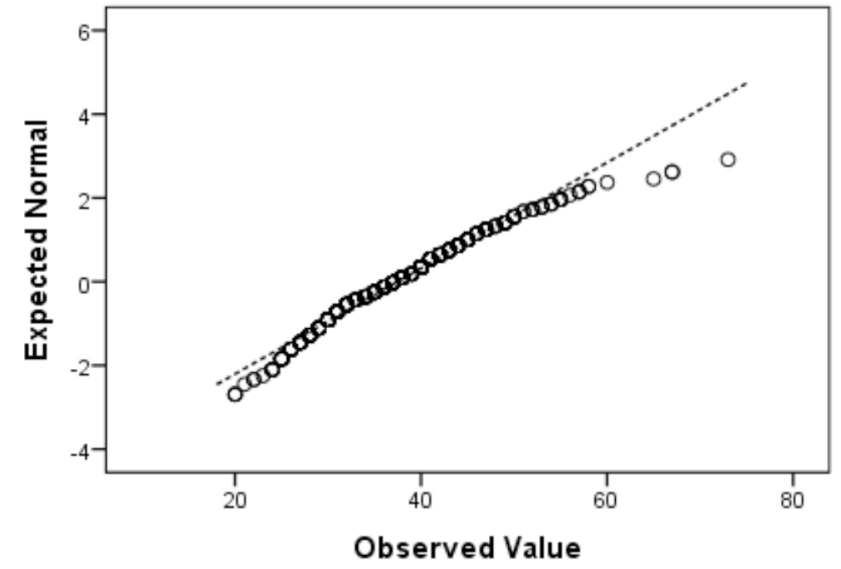

Fig. 2. Normal Q-Q plot of age illustrates that the age is not normally distributed.

percent, 7.56, 10.64, and percent 31.66 for MTS of head_length, head_width, length/width, head_area, head_perimeter, and acrosome, respectively. The mean results of the overall samples that were tested for head morphology parameters of normal sperm (MNS) and terato sperm (MTS) had similarity except for MNS_head_width $\mu \mathrm{m}(2.86 \mu \mathrm{m})$ and MTS_head_length_ $\mu \mathrm{m}(4.07 \mu \mathrm{m})$.
Descriptive statistics of the parameters of the morphological abnormality for the overall semen samples (Table II).

The sperm with normal morphology in the normal and abnormal semen samples indicated to be as 18.81 and 7.00 percent, respectively. The semen samples were examined to look for different types of sperm abnormality that include head, neck and tail abnormality.

The mean percent for head abnormality in the normal semen was recognized to be $0.67,19.59,16.45,18.01$, $5.06,28.00,5.63,15.06$ and 0.13 for the sperm cells with big head, small head, tapered head, pyriform head, round head, amorphous, vacuolated, small acrosome and double head respectively. Whereas the head abnormalities were founded to be 1.38, 27.30, 18.42, 17.74, 5.00, 31.44, 9.84, 23.09 and 0.75 for the sperm cells with big head, small head, tapered head, pyriform head, round head, amorphous, vacuolated, small acrosome and double head respectively. The results revealed a higher values of head abnormality for the sperm cells in the abnormal semen.

The semen samples were also tested for neck abnormality of the sperm cells in the normal and abnormal 
ALARABI, T. G. M. ; ALI, Q. M.; ABDALLA, A. M.; MOHAMMED, H. M.; EBRAHEEM, M.; HARUN, N. A.; SIDEEG, A. M. B. \& SALIH, A. G. K. A. Reference values (RV), MNS and MTS for morphological characteristics of normal and abnormal human spermatozoon describing teratozoospermic index (tzi) \& sperm deformity index (sdi) in sudanese infertile couples using CASA system. Int. J. Morphol., 37(3):1038-1045, 2019.

Table I. Illustrates the descriptive statistics of Mean of head morphology parameters of normal sperm (MNS) and terato sperm (MTS) of the overall samples.

\begin{tabular}{|c|c|c|c|c|c|}
\hline $\begin{array}{l}\text { Normal sperm (MNS) and } \\
\text { Terato sperm (MTS) of the } \\
\text { overall samples }\end{array}$ & Mean & $\begin{array}{l}\text { Standard } \\
\text { Deviation }\end{array}$ & Maximum & Minimum & Range \\
\hline \multicolumn{6}{|c|}{ MNS } \\
\hline MNS_head_length_ $\mu \mathrm{m}$ & 2.86 & 2.32 & 42.70 & .00 & 42.70 \\
\hline MNS_head_width_ $\mu \mathrm{m}$ & 2.08 & 1.21 & 7.09 & .00 & 7.09 \\
\hline MNS_length/width \% & 1.60 & 8.40 & 142.00 & .00 & 142.00 \\
\hline MNS_head_area_ $\mu \mathrm{m}$ & 5.98 & 3.64 & 35.23 & .00 & 35.23 \\
\hline MNS_head_perimeter_ $\mu \mathrm{m}$ & 9.93 & 45.47 & 1074.00 & .00 & 1074.00 \\
\hline MNS_acrosome $\%$ & 30.46 & 18.27 & 56.00 & .00 & 56.00 \\
\hline \multicolumn{6}{|c|}{ MTS } \\
\hline MTS_head_length_ $\mu \mathrm{m}$ & 4.07 & 2.95 & 42.51 & .00 & 42.51 \\
\hline MTS_head_width_ $\mu \mathrm{m}$ & 2.68 & 3.20 & 71.00 & .00 & 71.00 \\
\hline MTS_length/width \% & 1.60 & .57 & 9.44 & .00 & 9.44 \\
\hline MTS_head_area_ $\mu \mathrm{m}$ & 7.56 & 1.61 & 20.11 & .00 & 20.11 \\
\hline MTS_head_perimeter_ $\mu \mathrm{m}$ & 10.64 & 4.07 & 93.98 & .00 & 93.98 \\
\hline MTS_acrosome $\%$ & 31.66 & 18.48 & 377.79 & .00 & 377.79 \\
\hline
\end{tabular}

Table II. Illustrates the descriptive statistics of the parameters of the morphological abnormality for the normal and abnormal samples.

\begin{tabular}{|c|c|c|c|c|c|c|c|c|c|c|}
\hline & \multicolumn{10}{|c|}{ Overall evaluation } \\
\hline & \multicolumn{5}{|c|}{ Normal semen analysis } & \multicolumn{5}{|c|}{ Abnormal semen analysis } \\
\hline & $\begin{array}{c}\text { Mean } \\
\%\end{array}$ & $\begin{array}{c}\text { Standard } \\
\text { Deviation }\end{array}$ & Median & Minimum & Maximum & $\begin{array}{c}\text { Mean } \\
\%\end{array}$ & $\begin{array}{c}\text { Standard } \\
\text { Deviation }\end{array}$ & Median & Minimum & Maximum \\
\hline Jormal sperms) & 18.81 & 3.04 & 18.30 & 10.50 & 35.90 & 11.93 & 7.00 & 11.29 & .00 & 93.80 \\
\hline \multicolumn{11}{|c|}{ Head abnormalities: } \\
\hline g_head & .67 & 4.37 & .00 & .00 & 29.00 & 1.38 & 6.09 & .00 & .00 & 64.00 \\
\hline nal_head & 19.59 & 15.33 & 14.00 & .00 & 58.00 & 27.30 & 22.23 & 22.00 & .00 & 100.00 \\
\hline ıpered_Head & 16.45 & 12.25 & 14.00 & .00 & 50.00 & 18.42 & 17.55 & 17.00 & .00 & 100.00 \\
\hline rriform_Head & 18.01 & 15.49 & 17.00 & .00 & 63.00 & 17.74 & 16.22 & 17.00 & .00 & 67.00 \\
\hline sund_head & 5.06 & 9.56 & .00 & .00 & 50.00 & 5.00 & 10.14 & .00 & .00 & 83.00 \\
\hline morphus & 28.00 & 16.21 & 29.00 & .00 & 71.00 & 31.44 & 19.10 & 33.00 & .00 & 100.00 \\
\hline acuolated & 5.63 & 8.13 & .00 & .00 & 33.00 & 9.84 & 12.85 & .00 & .00 & 60.00 \\
\hline nall_Acrosome & 15.06 & 19.83 & 9.00 & .00 & 71.00 & 23.09 & 24.17 & 14.00 & .00 & 100.00 \\
\hline ouble_Head & .13 & 1.18 & .00 & .00 & 11.00 & .75 & 3.02 & .00 & .00 & 17.00 \\
\hline \multicolumn{11}{|c|}{ Neck abnormalities: } \\
\hline lin_Neck & .16 & 1.50 & .00 & .00 & 14.00 & .35 & 2.80 & .00 & .00 & 40.00 \\
\hline snt_Neck & 7.78 & 9.42 & .00 & .00 & 33.00 & 14.75 & 14.37 & 13.00 & .00 & 67.00 \\
\hline lick_or_Irregular & 6.10 & 9.43 & .00 & .00 & 40.00 & 5.60 & 11.33 & .00 & .00 & 100.00 \\
\hline symm_connect & 14.66 & 11.55 & 14.00 & .00 & 43.00 & 14.02 & 12.30 & 13.00 & .00 & 50.00 \\
\hline \multicolumn{11}{|c|}{ Tail abnormalities: } \\
\hline lort_tail & 4.51 & 6.58 & .00 & .00 & 30.00 & 6.78 & 10.48 & .00 & .00 & 83.00 \\
\hline snt_tail & 23.61 & 17.52 & 23.00 & .00 & 63.00 & 23.72 & 16.28 & 22.00 & .00 & 83.00 \\
\hline ulti_Tail & .62 & 2.89 & .00 & .00 & 17.00 & 1.30 & 5.66 & .00 & .00 & 80.00 \\
\hline iil_Break_down & 2.34 & 5.78 & .00 & .00 & 30.00 & 4.35 & 7.77 & .00 & .00 & 33.00 \\
\hline Jiled_tail & 14.23 & 11.64 & 14.00 & .00 & 43.00 & 15.11 & 11.86 & 14.00 & .00 & 60.00 \\
\hline egular_tail & .26 & 1.77 & .00 & .00 & 14.00 & .82 & 3.71 & .00 & .00 & 32.29 \\
\hline
\end{tabular}

semen samples. The result included neck abnormalities that are mainly seen as thin neck, bent neck, thick - irregular neck and asymmetric connected neck with a mean value of $0.16,7.78,6.10$ and 14.66 percent, respectively for the normal semen samples. Whereas for the abnormal semen it was $0.35,14.75,5.60$ and 14.02 , respectively.
Tail abnormalities were also observed during the normal and abnormal semen analysis. And the report of the results revealed tail abnormalities for the normal semen samples as short tail, bent tail, multi tail, tail-break-down, coiled tail and irregular tail with a percentage of 4.51, 23.61, $0.62,2.34,14.23$ and 0.26 percent, whereas it was 6.78 , 
ALARABI, T. G. M. ; ALI, Q. M.; ABDALla, A. M.; MOHAMMED, H. M.; EBRAHEEM, M.; HARUN, N. A.; SIDEEG, A. M. B. \& SALIH, A. G. K. A. Reference values (RV), MNS and MTS for morphological characteristics of normal and abnormal human spermatozoon describing teratozoospermic index (tzi) \& sperm deformity index (sdi) in sudanese infertile couples using CASA system. Int. J. Morphol., 37(3):1038-1045, 2019.

Table III. TZI and SDI of the overall sample.

\begin{tabular}{llll}
\hline Index of abnormality (in range) & $\mathrm{N}$ & Frequency (\%) \\
\hline TZI & $<0.5$ & 10 & 1.8 \\
& $0.5-1.0$ & 4 & 0.7 \\
& $1.0-1.5$ & 181 & 32.0 \\
& $<1.5$ & 195 & 34.5 \\
& $1.5-2.0$ & 168 & 29.7 \\
& $2.0-2.5$ & 154 & 27.2 \\
& $2.5-3$ & 37 & 6.5 \\
& $>3$ & 12 & 2.1 \\
Total & & 566 & $100 \%$ \\
SDI & $<0.5$ & 7 & 1.2 \\
& $0.5-1.0$ & 6 & 1.1 \\
& $1.0-1.5$ & 226 & 39.9 \\
& $<1.5$ & 239 & 42.2 \\
& $1.5-2.0$ & 166 & 29.3 \\
& $2.0-2.5$ & 133 & 23.5 \\
& $2.5-3$ & 15 & 2.7 \\
Total & $>3$ & 13 & 2.3 \\
\hline
\end{tabular}

$23.72,1.30,4.35,15.11$ and 0.82 for the abnormal semen samples, respectively.

Teratozoospermic index (TZI) \& Sperm deformity index (SDI) Index (Table III).

The study samples showed a frequency of 1.8, 0.7, 32.0, 29.7, 27.2, 6.5, and 2.1 percent for the TZI and 1.2, $1.1,39.9,29.3,23.5,2.7$, and 2.3 percent for the SDI, respectively (Table IV).

Teratozoospermic Index (TZI) of the overall study samples ranged from 0.00 to 3.94 with a standard deviation of $(0.52)(\mu \mathrm{m} / \mathrm{s})$ and mean of $(1.83)(\mu \mathrm{m} / \mathrm{s})$. Sperm Deformity Index (SDI) of the overall study samples ranged from 0.00 to 3.47 with a standard deviation of $(0.50)(\mu \mathrm{m} / \mathrm{s})$ and a mean of $(1.70)(\mu \mathrm{m} / \mathrm{s})$.

TZI and SDI for the normal and abnormal semen sample analysis (Table V).

Table IV. Mean and standard deviation of TZI and SDI of the overall samples.

\begin{tabular}{cccccc}
\hline & Mean & Standard Deviation & Range & Minimum & Maximum \\
\hline TZI & 1.83 & 0.52 & 3.94 & 0.00 & 3.94 \\
SDI & 1.70 & 0.50 & 3.47 & 0.00 & 3.47 \\
\hline
\end{tabular}

Table V. Descriptive statistics of the TZI and SDI of the normal and abnormal samples.

\begin{tabular}{llcccc}
\hline TZI and SDI index & \multicolumn{3}{c}{$\begin{array}{c}\text { Semen Types } \\
\text { Abnormal semen }\end{array}$} \\
& & Normal semen & \multicolumn{3}{c}{ Frequency (\%) } \\
\hline 'ZI & $<0.5$ & 1 & 1.2 & 9 & 1.9 \\
& $0.5-1.0$ & 2 & 2.3 & 2 & 0.4 \\
& $1.0-1.5$ & 66 & 75.9 & 115 & 24.0 \\
& $1.5-2.0$ & 17 & 19.5 & 151 & 31.5 \\
& $2.0-2.5$ & 1 & 1.1 & 153 & 31.9 \\
& $2.5-3$ & 0 & 0.0 & 37 & 7.7 \\
& $>3$ & 0 & 0.0 & 12 & 2.5 \\
'otal & & 87 & 100 & 479 & 100 \\
DI & $<0.5$ & 0 & 0.0 & 7 & 1.5 \\
& $0.5-1.0$ & 3 & 3.4 & 3 & 0.6 \\
& $1.0-1.5$ & 83 & 95.4 & 143 & 29.9 \\
& $1.5-2.0$ & 0.0 & 0.0 & 166 & 34.7 \\
& $2.0-2.5$ & 1 & 1.1 & 132 & 27.6 \\
& $2.5-3$ & 0.0 & 0.0 & 15 & 3.1 \\
& $>3$ & 0.0 & 0.0 & 13 & 2.7 \\
'otal & & 87 & 100 & 479 & 100 \\
\hline
\end{tabular}

Table VI show the Kolmogorov-Smirnov test of normality of distribution of the husband's age.

\begin{tabular}{cccclll}
\hline \multicolumn{5}{l}{ Kolmogorov-Smirnova } & \multicolumn{2}{l}{ Shapiro-Wilk } \\
& Statistic & Df & Sig. & Statistic & Df & Sig. \\
\hline Age & .076 & 564 & .000 & .975 & 564 & .000 \\
\hline
\end{tabular}

Overall semen abnormalities. From the all abnormal semen reports $(n=479)$ the common semen abnormalities were oligoasthenoteratozoospermia, asthenoteratozoospermia and asthenozoospermia with percentage of $32.36 \%, 30.06 \%$ and $25.05 \%$ respectively. Otherwise the remaining abnormalities (azoopyospermia, azoospermia, hypospermia, oligoasthenozoospermia and teratozoospermia were of low percentage on overall abnormal semen reports.

Effect of age. In order to test the effect of age we should check the normality of distribution of the age variable. Tests of normality (Table VI).

Lilliefors Significance Correction. The Kolmogorov-Smirnov test of normality reveals a $P$ value of 0.00 . This means that the null hypothesis: the age is normally distributed is rejected because the $\mathrm{P}$ value is $<0.05$. This indicates that the age is not normally distributed. 
ALARABI, T. G. M. ; ALI, Q. M.; ABDALLA, A. M.; MOHAMMED, H. M.; EBRAHEEM, M.; HARUN, N. A.; SIDEEG, A. M. B. \& SALIH, A. G. K. A. Reference values (RV), MNS and MTS for morphological characteristics of normal and abnormal human spermatozoon describing teratozoospermic index (tzi) \& sperm deformity index (sdi) in sudanese infertile couples using CASA system. Int. J. Morphol., 37(3):1038-1045, 2019.

\section{DISCUSSION}

The study results indicated that the normal and abnormal semen samples consisted of sperm cells with a low percentage of 18.81 and 11.93 percent respectively. This low percentage of sperm cells with normal morphology was as a result of different abnormalities which was mainly related to head, neck and tail abnormality.

The prevalence of abnormalities related to head in the normal sperm was recognized to be big head $(0.67 \%)$, small head $(19.59 \%)$, tapered head $(16.45 \%)$, pyriform head $(18.01 \%)$, round head $(5.06 \%)$, amorphous $(28 \%)$, vacuolated $(5.63 \%)$, small acrosome $(15.06 \%)$ and double head (0.13), respectively, Shows a higher prevalence of amorphous sperm cells $(28 \%)$. Whereas the prevalence of head abnormalities in the normal semen was 1.38 percent, 27.30 percent, 18.42 percent, 17.74 percent, 5.00 percent, 31.44 percent, 9.84 percent, 23.09 percent and 0.75 percent, indicating a higher prevalence of amorphous sperm cells $(31.44 \%)$ which is similar to the normal semen sperm cells. In general, the results revealed higher prevalence of different head abnormalities of sperm cells in the abnormal semen.

According to Auger et al. (2015), the 5th percentile for the percentage of normal spermatozoa including all borderline aspects was 23 percent (95\% CI, 20-26), which doesn't have much significant difference to this study results. Head abnormalities were documented as more frequent than midpiece and principal piece defects being classified as Tapered head (3\%), thin head (14\%), microcephallic (7 $\%)$, macrocephalic (1\%), multiple heads ( $2 \%)$, abnormal acrosomal region (60\%), and this study also showed a similar result for the head abnormality as Tapered head (16.45 $\%)$, microcephallic $(19.59 \%)$, macrocephalic $(0.67 \%)$, multiple heads $(0.13 \%)$, abnormal (small) acrosomal region $(15.06 \%)$. Midpiece texture or outline abnormalities of the acrosomal or post acrosomal regions were markedly more frequent among head abnormalities than head size abnormalities. Bent and coiled tails were the most frequent flagellar abnormalities were observed in most samples. In most fertile men, abnormal sperm cells generally had fewer than two associated abnormalities (95th percentile of MAI=1.92) (Auger et al.).

The semen samples were also checked for various neck abnormalities of the sperm cells in the normal and abnormal semen samples. The results revealed a 0.16 percent, 7.78 percent, 6.10 percent and 14.66 percent of as thin neck, bent neck, thick - irregular neck and asymmetric connected neck abnormalities in the normal sperm cells. Thin neck (14.66\%) abnormality was observed to be the most highly prevalent of the abnormalities in the normal semen. Whereas in the abnormal semen the prevalence of neck abnormalities was observed to be as, thin neck $(0.35 \%)$, bent neck ( 14.75 $\%)$, thick - irregular neck (5.60\%) and asymmetric connected neck abnormalities $(14.02 \%)$ respectively showing a higher prevalence of bent neck with 14.75 percent which is different from that of normal semen sperm cells. In general, the results of each neck abnormality of the sperm cells was observed to be higher in the abnormal semen than that of normal semen as that of head abnormalities.

In the semen analysis process, different sperm cell tail abnormalities were also identified these abnormalities were explained as short tail (4.51\%), bent tail (23.61\%), multi tail $(0.62 \%)$, tail-break-down $(2.34 \%)$, coiled tail $(14.23 \%)$ and irregular tail $(0.26 \%)$ for the normal semen samples; and 6.78 percent, 23.72 percent, 1.30 percent, 4.35 percent, 15.11 percent and 0.82 percent short tail, bent tail, multi tail, tail-break-down, coiled tail and irregular tail, respectively. Even though the prevalence of tail abnormalities is most higher than that of head and neck abnormalities, both results of the tail abnormalities indicated that bent tail as the more prevalent in normal (23.61 \%), and abnormal (23.72 $\%)$ semen sperm cells.

The results of the morphological abnormality of sperm in the normal and abnormal semen had shown a great difference among the head, neck and tail as compared to the normal semen samples.

The mean of head morphology parameters of normal sperm (MNS) and terato sperm (MTS) of the overall samples were also found to be $2.86 \mu \mathrm{m}, 2.08 \mu \mathrm{m}, 1.60$ percent, 5.98, 9.93, and 30.46 percent for head_length, head_width, length/width, head_area, head_perimeter, and acrosome, respectively for the MNS. Whereas it was also identified as $4.07 \mu \mathrm{m}, 2.68 \mu \mathrm{m}, 1.60$ percent, 7.56, 10.64, and percent 31.66 for MTS of head_length, head_width, length/width, head_area, head_perimeter, and acrosome, respectively. The mean results of the overall samples that were tested for head morphology parameters of normal sperm (MNS) and terato sperm (MTS) had similarity except for MNS_head_width_ $\mu \mathrm{m}(2.86 \mu \mathrm{m})$ and MTS_head_length $\mu \mathrm{m}(4.07 \mu \mathrm{m})$. The head should be covered by acrosome cap region covering 40 to 70 percent of the head area (Menkveld et al., 2001). A study of (Coppola et al., 2014) in 2000 digitalized sperm heads were analyzed for length, width, perimeter area using Digital Enhanced Sperm Analysis (DESA) technique revealed that the mean values for length, width, perimeter and area of normal sperm heads were $5.18 \pm 0.64 \mathrm{~mm}$ (mean $\pm \mathrm{SD}$ ) (range: 3.63 to 7.87 ), $3.53 \pm 0.45 \mathrm{~mm}$ (range: 2.37 to 5.62 ), $13.75 \pm 1.35 \mathrm{~mm}$ (range: 9.64 to 19.68 ), $14.12 \pm 3.03 \mathrm{~mm}^{2}$ (range: 7.77 to 
ALARABI, T. G. M. ; ALI, Q. M.; ABDALLA, A. M.; MOHAMMED, H. M.; EBRAHEEM, M.; HARUN, N. A.; SIDEEG, A. M. B. \& SALIH, A. G. K. A. Reference values (RV), MNS and MTS for morphological characteristics of normal and abnormal human spermatozoon describing teratozoospermic index (tzi) \& sperm deformity index (sdi) in sudanese infertile couples using CASA system. Int. J. Morphol., 37(3):1038-1045, 2019.

25.82). so, the results of his study agree with some parameters related this study. Although the WHO (2010) reference values mean (SD) for head legth and width were 4.1 (3.74.7) and 2.8 (2.5-3.2), the MNS parameters of WHO (1999) study for head_length, head_width, length/width, head_area, head_perimeter, and acrosome were $4.0-5.0 \mu \mathrm{m}, 2.5-3.5$ $\mu \mathrm{m}, 1.5-1.75 \%, 7.85-15.1 \mu \mathrm{m}, 10.8-14.9 \mu \mathrm{m}$ and 40 to 70 percent respectively and that agreed to most of the parameters of this study. The study results (agreed with our results) of (Maree et al., 2010) using CASA for the head length and width, where the mean value (SD) were 4.28 $(0.27)$ and $2.65(0.19)$ respectively.

The study samples showed a higher frequency $(32.0$ $\%$ ) of TZI in the range of $1.0-1.5$ and $(34.5 \%)$ were $<1.5$, whereas a higher frequency $(39.9 \%)$ of SDI was also observed also in the same range $(1.0-1.5)$ and $(42.2 \%)$ were $<1.5$. The study results indicated that the Teratozoospermic Index (TZI) frequency of the overall study sperm cells samples to fall in the frequency range 0.00 to 3.94 percent and mean of (1.83). whereas the Sperm Deformity Index (SDI) of sperm cells samples also were observed to be in a frequency of 0.00 to 3.47) and a mean of (1.70). According to WHO (1999), the teratozoospermic index values should read between 1.00 (each abnormal spermatozoon has only one defect) to 3.00 (each abnormal spermatozoon has head, midpiece, and tail defects). Some previous reports suggest that a TZI of more than 1.6 is always associated with lower pregnancy rates in untreated infertile couples (Jouannet et al., 1988) and the SDI of 1.6 considered as threshold for failure of in vitro fertilization (Aziz et al., 1996). Whereas the WHO (2010) revealed that the normal reference values for TZI and SDI were up to 1.72 and 1.62 respectively.

A significant association at $(\mathrm{P}$ value $=0.002)$ and $(\mathrm{P}$ value $=0.013)$ was observed between age and the dynamic parameters, for the seminal fluid in class $\mathrm{A}+\mathrm{B}+\mathrm{C}$ count and Motile ratio $(\mathrm{A}+\mathrm{B}+\mathrm{C})$ conc. (million $/ \mathrm{ml})$. The results of the study also indicated that the negative correlation of dynamic parameter of Motile ratio $(\mathrm{A}+\mathrm{B}+\mathrm{C})$ concentration and age. This indicates that as the age increases the Motile ratio of sperm decreases. This is in agreement with the study of Sharma et al. (2015) which revealed that an epigenetics changes, DNA mutations along with chromosomal aneuploidies have been associated with increasing paternal age. In addition to increased risk of male infertility, paternal age has also been demonstrated to impact reproductive and fertility outcomes including a decrease in IVF/ICSI success rate and increasing rate of preterm delivery. Increasing paternal age has shown to increase the incidence of different types of disorders (Sharma et al.). A review study on measurement and significance of sperm morphology that was conducted by Menkveld et al. (2011) reported that with increasing age they observed a significant decreasing trend in the mean percentage of morphologically normal spermatozoa indicating a negative correlation $(r=-0.4156)$ and they identified that sperm morphology as a very sensitive semen parameter and that any adverse factor will first be reflected in the sperm morphology as a temporary decrease and after repeated exposure as a permanent decrease in normal sperm morphology.

From all abnormal semen samples $(n=479)$ the common semen abnormalities were oligoasthenoteratozoospermia, asthenoteratozoospermia and asthenozoospermia with percentages of $32.36 \%, 30.06 \%$ and $25.05 \%$ respectively. These findings agreed with the study of Nada et al. (2015) which revealed that the Idiopathic oligoathenoteratozoospermia (iOAT) is a common finding in the evaluation of male infertility, and partially with Masoumi et al. (2015) which study revealed that the major causes of infertility with male factors were varicocele, oligospermia and asthenospermia. Whereas according to (Glazer et al., 2017) the most common type of male infertility was oligospermia (including some cases with oligoteratospermia) with $(33.8 \%)$ men, followed by other causes/unspecified male factors of infertility $(11.4 \%)$. Otherwise the remaining abnormalities (azoopyospermia, azoospermia, hypospermia, oligoasthenozoospermia and teratozoospermia were of low percentage on overall abnormal semen reports.

ACKNOWLEDGMENTS.We wish to acknowledge the help of Dr. Mohammed Dfa Allah and to professor. Mamon Haj Ali.

ALARABI, T. G. M.A.; ALI, Q. M.; ABDALLA, A. M.; MOHAMMED, H. M.; EBRAHEEM, M.; HARUN, N. A.; SIDEEG, A. M. B. \& SALIH, A. G. K. A. Valores de referencia (RV), MNS y MTS para las características morfológicas de espermatozoides humanos normales y anormales que describen el índice teratozoospérmico (TZI) y el índice de deformidad del esperma (SDI) en parejas infértiles de Sudán que utilizan el sistema CASA. Int. J. Morphol., 37(3):1038-1045, 2019.

RESUMEN: Se realizó una determinación científica de la capacidad de fertilización de los espermatozoides mediante motilidad, viabilidad y exámenes morfológicos denominados criterios de fertilidad potencial. Algunos estudios previos documentan solamente el total de las tasas de defectos morfológicos sin incluir a los sujetos morfológicos. Como se registra en muchos estudios, el éxito de IUI, ICSI y FIV depende principalmente de la calidad del semen recolectado. Los objetivos de este trabajo fueron: 1) Determinar y clasificar los defectos morfológicos comunes y las tasas de espermatozoides; 2) Analizar el efecto de la edad en 
ALARABI, T. G. M. ; ALI, Q. M.; ABDALLA, A. M.; MOHAMMED, H. M.; EBRAHEEM, M.; HARUN, N. A.; SIDEEG, A. M. B. \& SALIH, A. G. K. A. Reference values (RV), MNS and MTS for morphological characteristics of normal and abnormal human spermatozoon describing teratozoospermic index (tzi) \& sperm deformity index (sdi) in sudanese infertile couples using CASA system. Int. J. Morphol., 37(3):1038-1045, 2019.

las anomalías de los espermatozoides y evaluar el impacto del medio ambiente en el cambio de las características normales de los espermatozoides; 3) Determinar los tipos comunes de anomalías en el semen (astenoterato-zoospermia, astenozoospermia, azoopiepermia, azoospermia, hipospermia, oligoastenoteratozoospermia, oligoastenozoopermia, oligoastenozoospermia y teratozoospermia); 4) Determinar el rango del índice teratozoospérmico (TZI) y el índice de deformidad del esperma (IDE). Se realizó un estudio prospectivo de series de casos en 566 hombres, de parejas infértiles, que solicitaban análisis de semen en laboratorios ULTRALAB y la sucursal de ULTRALAB del Centro de Reproducción Asistida de Sudán (SARC), Jartum, Sudán. La recolección de datos se realizó durante 20 meses, desde el 1 de abril de 2010 hasta el 31 de diciembre de 2011. El análisis de las muestras de semen se realizó mediante el análisis de semen asistido por computadora (CASA). Existen diferencias en la normalidad y anormalidad de los parámetros de la morfología de los espermatozoides entre la población sudanesa y otros estudios, incluidas las normas de la Organización Mundial de la Salud. Los parámetros SDI y TZI fueron más altos en el semen general, así como en muestras de semen anormales. Las anomalías comunes del semen fueron oligoastenatoatoospermia, astenoteratozoospermia y astenozoospermia. Existen diferencias en la morfología de los espermatozoides de los parámetros normales y anormales entre la población sudanesa y otros estudios que incluyen las normas de la Organización Mundial de la Salud.

PALABRAS CLAVE: Esperma; Semen; Morfología; Esperma.

\section{REFERENCES}

Auger, J.; Jouannet, P. \& Eustache, F. Another look at human sperm morphology. Hum. Reprod., 31(1):10-23, 2015.

Austin, C. R. Observations on the penetration of the sperm in the mammalian egg. Aust. J. Sci. Res. B, 4(4):581-96, 1951.

Austin, C. R. The capacitation of the mammalian sperm. Nature, 170(4321):326, 1952.

Aziz, N.; Buchan, I.; Taylor, C.; Kingsland, C. R. \& Lewis-Jones, I. The sperm deformity index: a reliable predictor of the outcome of oocyte fertilization in vitro. Fertil. Steril., 66(6):1000-8, 1996.

Bonde, J. P. Male reproductive organs are at risk from environmental hazards. Asian J. Androl., 12(2):152-6, 2010.

Coppola, G.; Di Caprio, G.; Wilding, M.; Ferraro, P.; Esposito, G.; Di Matteo, L.; Dale, R.; Coppola, G. \& Dale, B. Digital holographic microscopy for the evaluation of human sperm structure. Zygote, 22(4):446-54, 2014.

De Jonge C. Biological basis for human capacitation. Hum. Reprod. Update, 11(3):205-14, 2005.

Glazer, C. H.; Bonde, J. P.; Giwercman, A.; Vassard, D.; Pinborg, A.; Schmidt, L. \& Vaclavik Bräuner, E. Risk of diabetes according to male factor infertility: a register-based cohort study. Hum. Reprod., 32(7):1474-81, 2017.

Hansen, C.; Luben, T. J.; Sacks, J. D.; Olshan, A.; Jeffay, S.; Strader, L. \& Perreault, S. D. The effect of ambient air pollution on sperm quality. Environ. Health Perspect., 118(2):203-9, 2010.

Jouannet, P.; Ducot, B.; Feneux, D. \& Spira, A. Male factors and the likelihood of pregnancy in infertile couples. I. Study of sperm characteristics. Int. J. Androl., 11(5):379-94, 1988.
Maree, L.; du Plessis, S. S.; Menkveld, R. \& van der Horst, G. Morphometric dimensions of the human sperm head depend on the staining method used. Hum. Reprod., 25(6):1369-82, 2010.

Masoumi, S. Z.; Parsa, P.; Darvish, N.; Mokhtari, S.; Yavangi, M. \& Roshanaei, G. An epidemiologic survey on the causes of infertility in patients referred to infertility center in Fatemieh Hospital in Hamadan. Iran. J. Reprod. Med., 13(8):513-6, 2015.

Menkveld, R.; Holleboom, C. A. \& Rhemrev, J. P. Measurement and significance of sperm morphology. Asian J. Androl., 13(1):59-68, 2011.

Menkveld, R.; Wong, W. Y.; Lombard, C. J.; Wetzels, A. M.; Thomas, C. M.; Merkus, H. M. \& Steegers-Theunissen, R. P. Semen parameters, including WHO and strict criteria morphology, in a fertile and subfertile population: an effort towards standardization of in-vivo thresholds. Hum. Reprod., 16(6):1165-71, 2001.

Nada, E. A.; El Taieb, M. A.; Ibrahim, H. M. \& Al Saied, A. E. Efficacy of tamoxifen and l-carnitine on sperm ultrastructure and seminal oxidative stress in patients with idiopathic oligoasthenoteratozoospermia. Andrologia, 47(7):801-10, 2015.

Sharma, R.; Agarwal, A.; Rohra, V. K.; Assidi, M.; Abu-Elmagd, M. \& Turki, R. F. Effects of increased paternal age on sperm quality, reproductive outcome and associated epigenetic risks to offspring. Reprod. Biol. Endocrinol., 13:35, 2015.

World Health Organization (WHO). WHO Laboratory Manual for the Examination of Human Semen and Sperm-Cervical Mucus Interaction. Cambridge, Cambridge University Press, 1999.

World Health Organization (WHO). WHO Laboratory Manual for the Examination of Human Semen and Sperm-Cervical Mucus Interaction. Cambridge, Cambridge University Press, 2010.

Corresponding author:

Tarig Gasim Mohamed Alarabi Ahmed

Department of Anatomy and Embryology

Orotta College of Medicine and Health Sciences

SUDAN

Email: tarigfuture@gmail.com

Received: 24-01-2019

Accepted: 08-04-2019 